\title{
Keanekeragaman Tumbuhan yang diperjual-belikan di Nurseri Kranggan, Bekasi, Jawa Barat
}

\author{
Marina Silalahi ${ }^{* 1}$, Hotmaulina Sihotang ${ }^{2}$ \\ *e-mail:marina_biouki@yahoo.com; marinas.silalahi@uki.ac.id \\ ${ }^{1}$ Prodi Pendidikan Biologi FKIP, Universitas Kristen Indonesia, Jakarta, \\ ${ }^{2}$ Prodi Magister Adminiatrasi Pendidikan, Universitas Kristen Indonesia, Jakarta.
}

\begin{abstract}
Nursery is a places for buying, selling transactions and plants care in the urban. This study aims to reveal the diversity of plants that are traded in the Kranggan nursery, Bekasi, West Java. This research was conducted by surveying and interviewing nursery owners and managers to find out the types of plants being traded. Reponden was determined by purvosif sampling with criteria namely having a nursery of at least $100 \mathrm{~m} 2$ or having worked at the nursery for at least 2 years. The data obtained was analyzed descriptively statistically. Plants that are traded in Kranggan nursery vary greatly between one trader and another, namely between 93-140 species of plants. A total of a total of 197 plants were traded in the Kranggan nursery which were included in 158 genera and 76 families. When viewed from the habitus, most of the traded plants ( 86 species) are herbs, followed by trees (69 species), shrubs (36 species) and lianas (6 species). Mango (Mangifera indica), klengkeng (Euphoria longana), guava (Psidium guajava), are plants very potential to be developed because its favored by buyer. Bonsai plants such as anting putri (Wrightia religiosa) and Korean banyan (Ficus campanulata) have great economic and conservation potential because it has a high selling price and high fruiting frequency.
\end{abstract}

Keywords: Nursery, Wrightia religiosa, Ficus campanulata, Bekasi

\begin{abstract}
ABSTRAK
Nurseri merupakan salah satu tempat untuk transaksi jual-beli dan tempat pembibitan dan pemeliharaan tanaman di daerah perkotaan, namun penelitian tentang keanekaragaman masih terbatas. Penelitian ini bertujuan untuk mengungkapkan keanekaragaman tumbuhan yang diperjual-belikan di nurseri Kranggan, Bekasi, Jawa Barat. Penelitian ini dilakukan dengan survei dan wawancara kepada pemilik dan pengelola nurseri untuk mengetahui jenis-jenis tumbuhan yang diperjual-belikan. Reponden ditentukan dengan purvosif sampling dengan kriteria yaitu memiliki nurseri minimal $100 \mathrm{~m}^{2}$ atau telah bekerja di nurseri minimal 2 tahun. Data yang diperoleh dianalisa secara statistika deskriptif. Tumbuhan yang diperjual-belikan di nurseri Kranggan sangat bervariasi antara satu pedagang dengan pedangang lainnya yaitu antara 93-140 spesies setiap nurseri. Total keselurahan tumbuhan yang diperjual belikan di nurseri Kranggan 197 spesies yang terdidtribusi dalam 158 genus dan 76 famili. Sebagian besar (86 spesies) yang diperjual-belikan merupakan herba, diikuti dengan pohon (69 species), perdu (36 species) dan liana (6 species). Mangga (Mangifera indica), klengkeng (Euphoria longana), jambu biji (Psidium guajava) merupakan tanaman buah yang sangat potensial dikembangkan karena banyak digemari konsumen. Tanaman bonsai seperti anting putri (Wrightia religiosa) dan beringin korea (Ficus campanulata) sangat berpotensi dari segi ekonomi dan konservasi karena memiliki harga jual yang tinggi dan frekuensi berbuah tinggi.
\end{abstract}

Kata Kunci: Nursery, Wrightia religiosa, Ficus campanulata, Bekasi 


\section{PENDAHULUAN}

Perdagangan tumbuhan tumbuhan telah lama dilakukan oleh manusia dan diduga berkembang sejalan dengan perkembangan peradapan manusia. Getah kemeyan (Styrax spp.) telah diperdagang kan di Sumatera sejak abad ke 8 oleh pedagang yang berasal dari China dan India (Backer \& Van den Brink 1965; Boer \& Ella 2001). Secara empirik terlihat bahwa perdagangan atau jual-beli tumbuhan dapat dilakukan di berbagai tempat seperti pasar tradisional, pasar modern, balai pembibitan, dan pengembangan tanaman atau nurseri. Nurseri merupakan istilah yang juga dapat digunakan untuk tempat pembibitan, pemeliharaan, pengembangan dan transaksi jual-beli tanaman (Sihotang et al. 2019).

Di kota-kota besar seperti halnya di Jakarta dan daerah penyangga sekitarnya (Bekasi) banyak ditemukan nurseri sebagai salah satu jawaban untuk memenuhi kebutuhan masyarakat atau konsumen terhadap ketersediaan sumber tanaman (Sihotang et al. 2019). Lebih dinyatakannya bahwa pemilik nurseri menggunakan managemen dalam pembi bitan, pemeliharaan, dan pemilihan tanaman untuk mendukung pengembang an dan kelangsungan nurseri. Tanaman diperjual-belikan di nurseri (Sihotang et al. 2019) dan pasar (Iskandar et al. 2018) bervariasi antar satu pedagang dengan pedagang lainnya.

Pasar tradisional, pasar modern (Iskandar et al. 2018) dan nurseri (Sihotang et al. 2019) menjadi sumber utama dalam penyediaan tanaman di daerah perkotaan yang digunakan sebagai peneduh, penghasil buah, maupun sebagai tanaman pekarangan. Setiap lokasi perdagangan tanaman memiliki kelebihan dan kekurangan. Perdagangan tanaman di pasar tradisional (Iskandar et al. 2018) dan nurseri memungkinkan adanya interaksi secara langsung antara pembeli dan pedagang, sedangkan pada pasar modern hal tersebut jarang terjadi. Selain memiliki kesamaan, beberapa perbedaan yang ditemukan antara perdangan tumbuhan di pasar tradisonal maupun modern dengan nurseri meliputi luas lahan, keanekaragaman jenis tanaman dan managemen. Untuk menja ga kelangsungan dan pengembangan nurseri menerapkan berbagai managemen dalam pembibitan, konsolidasi, pemeliha raan, dan penyiangan (Sihotang et al. 2019), yang jarang ditemukan di pasar.

Perdagangan tumbuhan secara langsung maupun tidak langsung akan membuka lapangan pekerjaan sehingga dapat menopang perekonomian atau sebagai mata pencaharian bagi pemilik, pekerjanya, maupun pemasoknya (Iskandar et al. 2018). Selain berperan secara ekonomi, ternyata perdagangan tumbuhn juga menjadi salah satu usaha konservasi keanekaragaman hayati khususnya tumbuhan. Silalahi (2014) menyatakan bahwa sebagian pedagang tumbuhan obat di pasar Kabanjahe membudidayakan tanaman yang diperjual belikan di pekarangan maupun di kebun nya. Pinus maximartinenzii ditemukan sebagai suatu spesies baru oleh etnobotanis Mexico melalui survei pasar (Martin 1995).

Transaksi jual-beli tumbuhan di nurseri mirip dengan transaksi di pasar tradisional yang memungkinkan pedagang dan pembeli bertemu dan aktivitas jual beli terjadi (Iskandar et al. 2018). Pasar tradisional sudah sejak lama ada di Indonesia sejak ada trasnaksi jual-beli berkembang di Indonesia (Supangkat 2012), namun berbeda halnya dengan nurseri yang baru berkembang pesat sejak tahun 2000 terutama di kota-kota besar seperti Jakarta maupun kota-kota di sekitarnya. Nurseri berkembang sejalan 
dengan makin meningkatnya tumbuhan yang dijadikan sebagai pelengkap di dalam ruangan maupun fungsi lain di luar ruangan. Salah satu kendala yang dihadapi oleh nurseri adalah keterbatasan untuk menghasilkan berbagai jenis anakan/bibit dan pemotongan buah, pohon hutan, dan bunga (Haque et al. 2007).

Tumbuhan yang diperdagangkan di setiap daerah umumnya berbeda sesuai dengan kebutuhan masyarakat setempat. Silalahi et al. (2015) menyatakan bahwa di Pasar Kabanjahe diperdagangkan sebanyak 345 spesies yang dijadikan masyarakat setempat sebagai bahan obat tradisional. Iskandar et al. (2018) menyatakan bahwa di pasar tradisional Ujung Berung sebagian besar tumbuhan yang diperdagangkan merupakan tanaman pangan yang meliputi 103 spesies merupakan sayuran, 58 spesies digunakan sebagai rempah-rempah, 39 spesies digunakan untuk buah-buahan, dan 10 sebagai makanan pokok atau sumber karbohidrat. Pasar tradisional diduga berbeda halnya dengan nurseri yang menyediakan berbagai jenis tumbuhan yang dapat dimanfaatkan sebagai sumber tanaman buah, tanaman hias, tanaman peneduh maupun tanaman jenis lainnya.

Volume dan jenis tumbuhan yang diperjualbelikan di nrseri dipengaruhi oleh faktor internal (modal dan luas nurseri) dan faktor eksternal (suplai dan permintaan dari konsumen). Nilai jual suatu tanaman dipengaruhi oleh berbagai faktor di antaranya suplai, manfaat, permintaan dan ukuran. Secara empirik terlihat tumbuhan yang memiliki ukuran lebih besar memiliki nilai jual yang lebih mahal dibandingkan dengan yang lebih kecil. Silalahi (2014) menyatakan bahwa setiap lembar daun tanaman "tapak raja sulaiman" (Hoya sp.) dijual hingga Rp.75.000/lembar daun sedangkan daun tanaman "bilalang manuk" (Dischidia sp.) dijual hingga 20.000/ lembar daun oleh pedagang tumbuhan obat di pasar Kabanjahe dan Berastagi Sumatera Utara.
Penelitian kenekaragaman tumbuhan yang diperjual-belikan di pasar sudah banyak dilaporkan baik di Indonesia seperti di pasar Kabanjahe (Silalahi et al. 2015), pasar Ujung Berung (Iskandar et al. 2018), pasar Berastagi (Nisyawati dan Silalahi 2015), pasar di Bali (Kriswiyanti et al. 2010), sedangkan penelitian di nurseri masih terbatas. Nova (2018) menyatakan nurseri diperjual-belikan berbagai jenis tumbuhan penghasil buah, hiasan, tumbuhan ritual, peneduh dan peneduh.

Bekasi merupakan salah satu kota yang berada di pingiran Jakarta dan merupakan salah satu kota pendukung untuk kelangsungan hidup kota Jakarta. Bila dibandingkan dengan Jakarta, Kota Bekasi relatif kurang padat yang mengakibatkan beberapa lahan di Kota Bekasi masih dapat difungsikan untuk membudidayakan atau tanaman yang dikenal juga sebagai nurseri. Penelitian ini bertujuan untuk mengkaji keanekaragaman tumbuhan yang diperjual-belikan di nursery Kranggan, Bekasi.

\section{BAHAN DAN METODE}

\section{Survei dan Wawancara}

Penelitian ini dilakukan di daerah Kranggan, Kelurahan Jatisampurna, Kecamatan Jatisampurna, Bekasi, Jawa Barat. Penelitian dilakukan pada September sampai November 2018. Wawancara intensif dan mendalam dilakukan kepada semua pemilik nurseri yang ada, dengan ketentuan memiliki lahan minimal $100 \mathrm{~m}^{2}$. Untuk melengkapi data dilakukan eksplorasi pada semua lahan kemudian dicatat nama lokal, habitus dan jumlah tumbuhan. Untuk ide Tumbuhan yanng di temukan dicatat nama lokalnya, diambil spesiemen bukti (voucher spesimen), sebagai bahan untuk identifikasi. Voucher spesimen di buat 
rangkap dua. Identifikasi voucher spesimen dilakukan dengan membandingkan dengan buku Flora of Java Vol II-III (Backer and van den Brik $1965 ; 1968)$.

\section{Analisis Data}

Analisis data dilakukan secara kualitatif meliputi pemanfaatan sebagai sarana pembelajaran maupun keanekaragamannya. Analisis keanekaragaman tumbuhan di sekolah dilakukan secara deskriptif dengan mengelompokkan tumbuhan berdasarkan habitus (pohon, perdu, herba), manfaat (tanaman hias, peneduh, maupun fungsi lainnya), genus dan famili

\section{HASIL DAN PEMBAHASAN \\ 1. Krakteristik Nurseri}

Nurseri yang dijadikan dalam penelitian ini merupakan nurseri yang memiliki luas lebih dari $100 \mathrm{~m}^{2}$. Setelah dilakukan survei di Kecamatan Jatisampurna Bekasi maka nurseri yang terdapat di jalan Kranggan Raya atau selanjutnya disebut Nurseri Kranggan (NK) merupakan nurseri yang memenuhi kriteria dalam penelitian ini. Nurseri Kranggan memilikiluas 100-500 $\mathrm{m}^{2}$ dengan jumlah pengelola antara 2-8 orang. Jumlah pengelola tergantung pada luas dan jumlah tanaman yang dikelolah dan semakin luas nurseri maka jumlah pengelola semakin banyak. Tugas utama pengelola nurseri berbeda-beda, namun terkadang saling melengkapi dan membantu satu dengan yang lainnya.

NK mulai berdiri sejak tahun 2005, namun awalnya hanya menjual dan memakai lahan kosong saja. Sejalan dengan pertambahan waktu dan meningkatkanya pasokan serta perminta an maka nurseri semakin berkembang dan dikelola semakin baik. jumlah tanaman yang diperjualbelikan semakin bervariasi, namun terkadang tergantung pada trend permintaan masyarakat. Pada tahun 20052010 nurseri banyak menjual tanaman hias terutanama dari jenis Anthurium, Aglaonema, dan Puring.

\section{Keanekaragaman Tumbuhan}

Tumbuhan yang diperjual-belikan di nurseri Kranggan sangat bervariasi antara satu pedagang dengan pedangang lainnya yaitu antara 93-140 spesies tumbuhan. Total keselurahan tumbuhan yang diperjual belikan di nurseri Kranggan 197 spesies yang termasuk dalam 158 g dan 76 famili (Tabel 1).

Tabel 1. Keanekaragaman Tumbuhan yang diperjual-belikan di Nurseri Kranggan (NK), Bekasi, Jawa Barat.

\begin{tabular}{|c|c|c|c|c|}
\hline Famili & Nama Ilmiah & Nama lokal & Nama Nurseri & Habitus \\
\hline \multirow[t]{3}{*}{ Acantaceae } & $\begin{array}{l}\text { Andrographis } \\
\text { paniculata }\end{array}$ & Sambiroto & EQ & Herba \\
\hline & Justicia gendarusa & Gendarusa & MM & Herba \\
\hline & Pachystachys lutea & Bunga lilin & EQ, MM & Herba \\
\hline Adiantaceae & Adiantum sp & Suplir & $\mathrm{BF}, \mathrm{EQ}, \mathrm{MM}, \mathrm{RN}$ & Herba \\
\hline Agavaceae & Agave variegata & Agave & $\mathrm{BF}, \mathrm{RN}$ & Herba \\
\hline Alismataceae & $\begin{array}{l}\text { Echinodorus } \\
\text { palifolius }\end{array}$ & Melati air & $\mathrm{MM}, \mathrm{RN}$ & Herba \\
\hline \multirow[t]{4}{*}{ Amarantaceae } & Alternathera reineckii & Erpa & $\mathrm{BF}$ & Herba \\
\hline & Amaranthus hibryda & Bayam & EQ & Herba \\
\hline & Celosia cistata & Jegger ayam & $\mathrm{BF}$ & Herba \\
\hline & Gomphrena globosa & Kancing bupati & $\mathrm{BF}, \mathrm{EQ}, \mathrm{MM}$ & Herba \\
\hline Amaryllidaceae & Crynum asiaticum & Bakung & $\mathrm{BF}, \mathrm{EQ}, \mathrm{MM}, \mathrm{RN}$, & Herba \\
\hline
\end{tabular}




\begin{tabular}{|c|c|c|c|c|}
\hline & & & SA & \\
\hline & Hymenocalia latifolia & Bunga lili & $\mathrm{BF}, \mathrm{RN}$ & Herba \\
\hline & Zephyranthes candida & Bunga bawang & $\mathrm{BF}, \mathrm{EQ}, \mathrm{RN}, \mathrm{SA}$ & Herba \\
\hline Anacardiaceae & $\begin{array}{l}\text { Anacardium } \\
\text { occidentale }\end{array}$ & Jambu mete & EQ & Pohon \\
\hline & Mangifera indica & Mangga & EQ, MM, RF, SA & Pohon \\
\hline Annonaceae & Anona muricata & Srikaya & EQ, MM & Pohon \\
\hline & Annona squamosa & Sirsak & $\mathrm{BF}, \mathrm{EQ}, \mathrm{RF}$ & Pohon \\
\hline & Cananga odorata & Kenanga & EQ, MM & Perdu \\
\hline & Polyalthia longifolia & Glodokan tiang & BF, EQ, MM, SA & Pohon \\
\hline Apiaceae & Centella asiatica & Pegagan & $\mathrm{BF}, \mathrm{RN}$ & Herba \\
\hline Apocynaceae & Adenium obesum & Kamboja jepang & $\begin{array}{l}\mathrm{BF}, \mathrm{EQ}, \mathrm{MM}, \mathrm{RF} \text {, } \\
\mathrm{SA}\end{array}$ & Herba \\
\hline & Alstonia shcolaris & Pulai & $\mathrm{BF}$ & Pohon \\
\hline & Allamanda cathartica & Alamanda & MM & Liana \\
\hline & Mandevila $s p$ & Mandeliva & $\mathrm{BF}, \mathrm{EQ}, \mathrm{MM}$ & Herba \\
\hline & Pulmeria rubra & Kamboja & $\begin{array}{l}\text { BF, EQ, MM, RF, } \\
\text { SA }\end{array}$ & Perdu \\
\hline & Tevetia puruviana & Bunga mentega & $\mathrm{BF}$ & Perdu \\
\hline & Wrightia religiosa & Anting putri & $\mathrm{BF}, \mathrm{EQ}, \mathrm{RN}, \mathrm{RF}$ & Pohon \\
\hline Araceae & Acorus calamus & Jerango & $\mathrm{BF}, \mathrm{RN}$ & Herba \\
\hline & Aglaonema crispum & Srirezeki & EQ, MM, RN, SA & Herba \\
\hline & $\begin{array}{l}\text { Anthurium } \\
\text { crystallinum }\end{array}$ & Kuping gajah & EQ, MM, RN, SA & Herba \\
\hline & Aglaonema sp.1 & Aglonema hijau & $\mathrm{BF}, \mathrm{MM}, \mathrm{RN}, \mathrm{SA}$ & Herba \\
\hline & Aglaonema sp.2 & Aglaonema merah & EQ, MM, RN,SA & Herba \\
\hline & Alocasia esculentum & Keladi Hitam & $\mathrm{BF}$ & Herba \\
\hline & Anthurium sp. & Anturium & $\mathrm{BF}, \mathrm{RN}, \mathrm{SA}$ & Herba \\
\hline & Dieffenbachia & Diefenbakias & EQ, MM, RN, SA & Herba \\
\hline & Epipremпит аигеuт & Sirih gading & EQ, MM, RN & Herba \\
\hline & Philodendron sp1. & $\begin{array}{l}\text { Philodendron } \\
\text { bolong daunya }\end{array}$ & $\mathrm{BF}, \mathrm{EQ}, \mathrm{MM}, \mathrm{RN}$ & Herba \\
\hline & Philodendron sp2. & Philodendron 2 & EQ, MM, RN, SA & Herba \\
\hline & Philodendron tricolor & Filo lemon & $\begin{array}{l}\text { BF, EQ, MM, RN, } \\
\text { SA }\end{array}$ & Herba \\
\hline & $\begin{array}{l}\text { Philodendron } \\
\text { williamsii }\end{array}$ & Filodendrom & $\begin{array}{l}\mathrm{BF}, \mathrm{EQ}, \mathrm{MM}, \mathrm{RN} \text {, } \\
\mathrm{SA}\end{array}$ & Herba \\
\hline & Pistia stratiotes & Kiambang & MM & Herba \\
\hline & $\begin{array}{l}\text { Zamioculcas } \\
\text { zamiifolia }\end{array}$ & Daun dolar & $\begin{array}{l}\text { BF, EQ, MM, } \\
\text { RN,SA }\end{array}$ & Herba \\
\hline Araliaceae & Schefflera aboricola & Walisongo & EQ, MM, RN, SA & Perdu \\
\hline Araucariaceae & $\begin{array}{l}\text { Araucaria } \\
\text { heterophylla }\end{array}$ & Cemara nurflok & $\begin{array}{l}\mathrm{BF}, \mathrm{EQ}, \mathrm{MM}, \mathrm{RN} \text {, } \\
\mathrm{SA}\end{array}$ & Pohon \\
\hline Arecaceae & Cocos nucifera & Kalapa & $\mathrm{EQ}, \mathrm{BF}$ & Pohon \\
\hline & Coccothrinax crinita & Palem jenggot & $\begin{array}{l}\text { BF, EQ, MM, RN, } \\
\text { SA }\end{array}$ & Pohon \\
\hline & $\begin{array}{l}\text { Crisalidocarpus } \\
\text { lutenscens }\end{array}$ & Palem Kuning & $\begin{array}{l}\mathrm{BF}, \mathrm{EQ}, \mathrm{MM}, \mathrm{RN} \text {, } \\
\mathrm{SA}\end{array}$ & Pohon \\
\hline & Cyrtostachys renda & Palem merah & EQ, MM, RN, SA & Pohon \\
\hline & Dypsis lutescens & $\begin{array}{l}\text { Palem kuning, } \\
\text { palem putri }\end{array}$ & EQ, MM, RN, SA & Pohon \\
\hline & $\begin{array}{l}\text { Hyophorbe } \\
\text { lagenicaulis }\end{array}$ & Pelem botol & $\begin{array}{l}\mathrm{BF}, \mathrm{EQ}, \mathrm{MM}, \mathrm{RN} \text {, } \\
\mathrm{SA}\end{array}$ & Pohon \\
\hline & Livistona saribus & Palem kipas & $\mathrm{BF}, \mathrm{EQ}, \mathrm{MM}, \mathrm{RN}$, & Pohon \\
\hline
\end{tabular}




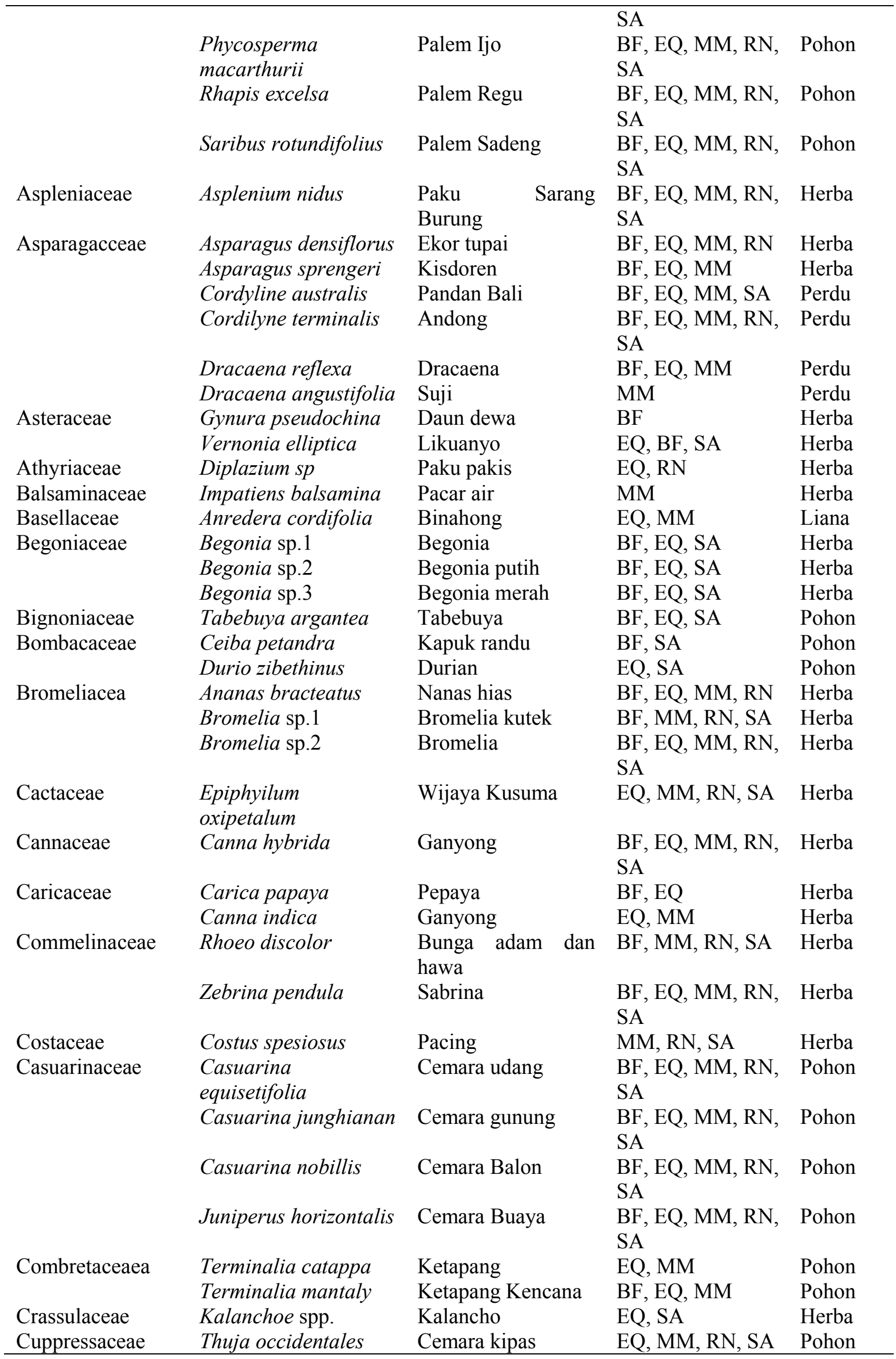




\begin{tabular}{|c|c|c|c|c|}
\hline Cycadaceae & Cycas revulota & Sikas & $\begin{array}{l}\text { BF, EQ, MM, RN, } \\
\text { SA }\end{array}$ & Pohon \\
\hline Cyperaceae & Cyperus papyrus & Papirus & MM & Herba \\
\hline Equisetaceae & Equisetum debile & Bambu air & $\mathrm{BF}, \mathrm{MM}, \mathrm{RN}, \mathrm{SA}$ & Herba \\
\hline \multirow[t]{6}{*}{ Euphorbiaceae } & Acalypha siamensis & Teh-tehan & $\mathrm{BF}, \mathrm{EQ}, \mathrm{SA}$ & Perdu \\
\hline & Codieaum varigatum & Puring & $\begin{array}{l}\mathrm{BF}, \mathrm{EQ}, \mathrm{MM}, \mathrm{RN} \text {, } \\
\mathrm{SA}\end{array}$ & Perdu \\
\hline & $\begin{array}{l}\text { Ecoecaria } \\
\text { cochinchinensis }\end{array}$ & Sampang Darah & $\mathrm{BF}, \mathrm{EQ}, \mathrm{MM}, \mathrm{SA}$ & Perdu \\
\hline & Euphorbia millii & Euphorbia & BF, EQ, MM & Herba \\
\hline & Jatropha pandurifolia & Batavia & EQ, RN, MM, SA & Perdu \\
\hline & $\begin{array}{l}\text { Pedilanthus } \\
\text { bracteatus }\end{array}$ & Zigzag & $\mathrm{BF}, \mathrm{EQ}, \mathrm{MM}$ & Herba \\
\hline \multirow[t]{2}{*}{ Fabaceae } & Arachis pintoi & Kacang-kacangan & EQ, BF, RN, SA & Herba \\
\hline & Delonix regia & Flamboyan & EQ & Pohon \\
\hline Gesneriaaceae & $\begin{array}{l}\text { Aeschynanthus } \\
\text { radicans }\end{array}$ & Gesneria & EQ & Herba \\
\hline \multirow[t]{2}{*}{ Heloconiaceae } & $\begin{array}{l}\text { Heliconia } \\
\text { paittacorum }\end{array}$ & Cepit Udang & $\mathrm{BF}, \mathrm{MM}$ & Herba \\
\hline & Heliconia sp & Helikonia & $\mathrm{BF}, \mathrm{MM}$ & Herba \\
\hline \multirow[t]{3}{*}{ Lamiacea } & Coleus blumei & Miana & $\begin{array}{l}\text { BF, EQ, MM, RN, } \\
\text { SA }\end{array}$ & Herba \\
\hline & Lavandula afficinalis & Lavender & EQ, RN, SA & Herba \\
\hline & $\begin{array}{l}\text { Orthosiphon } \\
\text { stamineus }\end{array}$ & Kumis Kucing & BF, SA & Perdu \\
\hline \multirow[t]{4}{*}{ Liliaceae } & Aloe vera & Lidah buaya & BF, EQ, MM, SA & Herba \\
\hline & Lilium sp & Lili Ubi & BF, MM, SA & Herba \\
\hline & $\begin{array}{l}\text { Ophiopogon } \\
\text { japonicus }\end{array}$ & Rumput kucai & EQ, MM, RN & Herba \\
\hline & Sansiviera sp. & Landong Luput & $\begin{array}{l}\mathrm{BF}, \mathrm{EQ}, \mathrm{MM}, \mathrm{RN} \text {, } \\
\mathrm{SA}\end{array}$ & Herba \\
\hline \multirow[t]{2}{*}{ Lythraceae } & Cuphea hyssopifolia & Taiwan & $\mathrm{BF}, \mathrm{EQ}, \mathrm{MM}, \mathrm{SA}$ & Perdu \\
\hline & Punica granatum & Delima & EQ & Perdu \\
\hline \multirow[t]{3}{*}{ Marantaceae } & Calathea lansifolia & Meranti hijau & EQ, MM & Herba \\
\hline & Calathea lutea & Pisang Talatea & EQ, SA & Herba \\
\hline & Marantha sp & Marantha & EQ & Herba \\
\hline \multirow[t]{9}{*}{ Moraceae } & Artocarpus artilis & Sukun & EQ & Pohon \\
\hline & $\begin{array}{l}\text { Artocarpus } \\
\text { heterophylla }\end{array}$ & Nangka & EQ, MM, SA & Pohon \\
\hline & $\begin{array}{l}\text { Ficus benjamiina } \\
\text { "variegata" }\end{array}$ & Beringin Variegata & $\mathrm{BF}, \mathrm{MM}$ & Pohon \\
\hline & Ficus benjamina & Beringin & EQ, MM, RN, SA & Pohon \\
\hline & Ficus campanulata & Beringin korea & $\mathrm{MM}, \mathrm{RN}, \mathrm{SA}$ & Pohon \\
\hline & Ficus elastica & $\begin{array}{l}\text { Karet hias/karet } \\
\text { kebo }\end{array}$ & EQ, MM, RN, SA & Pohon \\
\hline & Ficus lirata & Biola Cantik & EQ & Pohon \\
\hline & Morus alba & Murbei & BF, SA & Pohon \\
\hline & Streblus asper & Serut & $\mathrm{BF}$ & Perdu \\
\hline Magnoliaceae & Magnolia alba & Cempaka/Kantil & EQ, BF, SA & Perdu \\
\hline \multirow[t]{2}{*}{ Malvaceae } & Hibiscus rosa-sinensis & Kembang Sepatu & $\mathrm{BF}, \mathrm{EQ}, \mathrm{MM}, \mathrm{RN}$ & Perdu \\
\hline & Hibiscus tiliaceus & Waru hibrid & EQ & Pohon \\
\hline Musaceae & Musa paradisiaca & Pisang & EQ, SA & Herba \\
\hline \multirow[t]{2}{*}{ Myrtaceae } & Myrciaria cauliflora & Anggur Brazil & $\mathrm{BF}, \mathrm{RN}$ & Liana \\
\hline & Psidium guajava & Jambu Biji & $\mathrm{BF}, \mathrm{EQ}, \mathrm{MM}$ & Pohon \\
\hline
\end{tabular}




\begin{tabular}{|c|c|c|c|c|}
\hline & Syzigium aqueum & Jambu Air & $\begin{array}{l}\text { BF, EQ, MM, RF, } \\
\text { SA }\end{array}$ & Pohon \\
\hline & Syzygium aromaticum & Cengkeh & EQ & Pohon \\
\hline & Syzygium jambos & Jambu mawar & $\mathrm{EQ}, \mathrm{MM}$ & Pohon \\
\hline & Syzygium malaccense & Jambu bol & $\mathrm{EQ}, \mathrm{BF}, \mathrm{SA}$ & Pohon \\
\hline & Syzygium oleana & Pucuk Merah & $\begin{array}{l}\mathrm{BF}, \mathrm{EQ}, \mathrm{MM}, \mathrm{RN}, \\
\mathrm{SA}\end{array}$ & Pohon \\
\hline & Syzygium polipetaum & Gohok & $\mathrm{BF}$ & Pohon \\
\hline Nelumbonaceae & Nelumbo nucifera & Lotus & $\mathrm{BF}, \mathrm{RN}$ & Herba \\
\hline Nephrolepidaceae & Neprolephis exaltata & Pakis gunung & EQ, RN, SA & Pohon \\
\hline Nymphaceae & Nymphaea sp & Teratai & $\mathrm{MM}$ & Herba \\
\hline \multirow[t]{3}{*}{ Nyctaginaceae } & Bougenvillea glabra & Bugenvil putih & EQ, MM, RN, SA & Perdu \\
\hline & Bougenvillea hibrida & Bogenvil Hibrid & EQ, MM, RN, SA & Perdu \\
\hline & $\begin{array}{l}\text { Bougenvillea } \\
\text { spectabile }\end{array}$ & Bugenvil Orange & EQ, MM, RN, SA & Perdu \\
\hline \multirow[t]{2}{*}{ Oleaceae } & Jasminum sp. & Jasminum & EQ, MM, RN, SA & Perdu \\
\hline & Ligustrum & Laigestrum & MM & Perdu \\
\hline \multirow[t]{2}{*}{ Orchidaceae } & Dendrobium sp. & $\begin{array}{l}\text { Anggrek } \\
\text { Dendrobium }\end{array}$ & EQ & Herba \\
\hline & Phalaenopsis sp & Anggrek bulan & EQ & Herba \\
\hline \multirow[t]{2}{*}{ Oxalidaceae } & Averrhoa bilimbi & Belimbing wuluh & $\mathrm{BF}$ & Pohon \\
\hline & Averrhoa carambola & Belimbing buah & $\mathrm{EQ}, \mathrm{MM}$ & Pohon \\
\hline Pandanaceae & $\begin{array}{l}\text { Pandanus } \\
\text { amaryllifolius }\end{array}$ & Pandan & EQ, MM, SA & Herba \\
\hline Phyllanthaceae & $\begin{array}{l}\text { Phyllanthus } \\
\text { myrtifolius }\end{array}$ & Cendrawasih & MM & Herba \\
\hline Plassifloraceae & Passiflora edulis & Markisa & MM & Liana \\
\hline Piperaceae & Piper betle & Sirih & EQ & Liana \\
\hline \multirow[t]{4}{*}{ Poaceae } & Bambusa vulgaris & Bambu kuning & $\begin{array}{l}\mathrm{BF}, \mathrm{EQ}, \mathrm{MM}, \mathrm{RN}, \\
\mathrm{SA}\end{array}$ & Pohon \\
\hline & Cymbopogon citratus & Serai & $\mathrm{BF}$ & Herba \\
\hline & $\begin{array}{l}\text { Dendrocalamus } \\
\text { latiflorus }\end{array}$ & Bambu taiwan & MM, RN, SA & Pohon \\
\hline & $\begin{array}{l}\text { Thryrsostachys } \\
\text { siamensis }\end{array}$ & Bambu Jepang & MM, RN,SA & Pohon \\
\hline Polypodiaceae & $\begin{array}{l}\text { Plathycerium } \\
\text { bifurcatum }\end{array}$ & Paku Tanduk Rusa & EQ, RN, SA & Herba \\
\hline \multirow[t]{2}{*}{ Polygonaceae } & Antigonom leptosus & $\begin{array}{l}\text { Air Mata Pengantin } \\
\text { Pink }\end{array}$ & EQ, MM, RN & Liana \\
\hline & Coccoloba uvifera & Anggur rambat & $\mathrm{BF}$ & Liana \\
\hline Portulacaceae & Portulaca glandiflora & Krokot & $\mathrm{BF}, \mathrm{MM}, \mathrm{RN}, \mathrm{SA}$ & Herba \\
\hline \multirow[t]{4}{*}{ Rosaceae } & Fragaria virginiana & Stroberry & EQ & Herba \\
\hline & Malus domestica & Apel & $\mathrm{EQ}$, & Perdu \\
\hline & Muntingia calabura & Kersen & EQ & Pohon \\
\hline & Rosa hybrida & Mawar & $\mathrm{BF}, \mathrm{MM}$ & Perdu \\
\hline \multirow[t]{4}{*}{ Rubiaceae } & $\begin{array}{l}\text { Euodia ridleyi } \\
\text { Gardenia jamonoides }\end{array}$ & $\begin{array}{l}\text { Brokoli Hijau } \\
\text { Gardenia Variegata }\end{array}$ & $\begin{array}{l}\text { EQ, RN, SA, } \\
\text { BF RN, RN }\end{array}$ & $\begin{array}{l}\text { Perdu } \\
\text { Perdu }\end{array}$ \\
\hline & $\begin{array}{l}\text { Ixora javanica } \\
\text { "yellow" }\end{array}$ & Bunga soka & $\begin{array}{l}\mathrm{BF}, \mathrm{EQ}, \mathrm{MM}, \mathrm{RN} \text {, } \\
\mathrm{SA}\end{array}$ & Perdu \\
\hline & $\begin{array}{l}\text { Ixora javanica "super } \\
\text { king" }\end{array}$ & Soka merah & $\begin{array}{l}\mathrm{BF}, \mathrm{EQ}, \mathrm{MM}, \mathrm{RN} \text {, } \\
\mathrm{SA}\end{array}$ & Perdu \\
\hline & Ixora javanica & Soka beko & $\begin{array}{l}\mathrm{BF}, \mathrm{EQ}, \mathrm{MM}, \mathrm{RN}, \\
\mathrm{SA}\end{array}$ & Perdu \\
\hline
\end{tabular}




\begin{tabular}{|c|c|c|c|c|}
\hline & Ixora siaminensis & Asoka pink & $\begin{array}{l}\text { BF, EQ, MM, RN, } \\
\text { SA }\end{array}$ & Perdu \\
\hline & Ixora sp. & Asoka Orange & $\begin{array}{l}\text { BF, EQ, MM, RN, } \\
\text { SA }\end{array}$ & Perdu \\
\hline & Morinda citrifolia & Mengkudu & $\mathrm{BF}$ & Pohon \\
\hline & Mussaenda philipcica & Musaenda & EQ, MM, RN & Perdu \\
\hline \multirow[t]{7}{*}{ Rutaceae } & Citrus amblyacarpa & Jeruk Limau & $\mathrm{BF}, \mathrm{MM}$ & Pohon \\
\hline & Citrus aurantiafolium & Jeruk Nipis & $\mathrm{BF}, \mathrm{EQ}, \mathrm{RF}, \mathrm{SA}$ & Pohon \\
\hline & Citrus histryx & Jeruk purut & BF, EQ, MM & Pohon \\
\hline & Citrus maxima & Jeruk bali & MM & Pohon \\
\hline & Citrus nobilis & Jeruk pepaya & EQ & Pohon \\
\hline & Citrus sinensis & Jeruk Manis & $\mathrm{BF}$ & Pohon \\
\hline & Murraya paniculata & Kemuning & EQ, MM, RF & Perdu \\
\hline \multirow[t]{4}{*}{ Sapindaceae } & Euphoria longana & Klengkeng & EQ, & Pohon \\
\hline & Nephelium lappaceum & Rambutan & BF, EQ, MM & Pohon \\
\hline & Pometia pinnata & Matoa & MM & Pohon \\
\hline & Spondias dulcis & Kedondong & $\mathrm{BF}, \mathrm{EQ}, \mathrm{SA}$ & Pohon \\
\hline \multirow[t]{2}{*}{ Solanaceae } & Capsicum апnиuт & Cabe merah & EQ, RF & Herba \\
\hline & Capsicum frutescens & Cabe rawit & $\mathrm{RF}$ & Herba \\
\hline \multirow[t]{2}{*}{ Sapotaceae } & Manilkam kauki & Sawo kecik & MM & Pohon \\
\hline & Manilkara zapota & Sawo & EQ & Pohon \\
\hline Sapotaceae & $\begin{array}{l}\text { Synsepalum } \\
\text { dulcificum }\end{array}$ & Mirecle fruit & EQ & Pohon \\
\hline Scrophulariaceae & $\begin{array}{l}\text { Russelia } \\
\text { equisetiformis }\end{array}$ & Air Mancur & BF, EQ, MM & Herba \\
\hline Strelitziaceae & $\begin{array}{l}\text { Ravenala } \\
\text { madagascariensis }\end{array}$ & Pisang Hias & EQ, MM & Herba \\
\hline Selaginellaceae & Selaginella sp. & Selaginella & EQ, MM & Herba \\
\hline Stryracaceae & Styrax sp. & Kemeyan & $\mathrm{BF}$ & Pohon \\
\hline Thymeliaceae & Phaleria macrocarpa & Mahkota dewa & MM & Pohon \\
\hline \multirow[t]{3}{*}{ Verbenaceae } & $\begin{array}{l}\text { Clerodendrum } \\
\text { thomsoniae }\end{array}$ & Nona Makan Sirih & BF, EQ & Liana \\
\hline & Lantana camara & Tembelekan Orange & $\begin{array}{l}\text { BF, EQ, MM, RN, } \\
\text { SA }\end{array}$ & Perdu \\
\hline & $\begin{array}{l}\text { Lantana } \\
\text { montevidensis }\end{array}$ & Tembelekan Pink & $\begin{array}{l}\mathrm{BF}, \mathrm{EQ}, \mathrm{MM}, \mathrm{RN} \text {, } \\
\mathrm{SA}\end{array}$ & Perdu \\
\hline Zingiberaceae & Curcuma longa & Kunyit & EQ & Herba \\
\hline
\end{tabular}

Gambar 1 menunjukkan famili dengan jumlah spesies terbanyak yaitu Araceae (15 species), Arecaceae (10 species), Moraceae ( 9 spesies), dan Myrtaceae (8 species). Tingginya jumlah species Arace-ae yang diperjual-belikan di nurseri Kranggan diduga berhubungan dengan tingginya minat masyarakat untuk menjadikan tanaman ini sebagai tanaman hias di pekarangan. Silalahi (2018) menyatakan bahwa Araceae merupakan tanaman yang paling banyak ditemkan di pekarangan. Ukuran tanaman yang kecil, perawatan mudah dengan harga yang relatif murah menjadikan tanaman ini memiliki banyak konsumen.

Mytaceae merupakan salah satu jenis pohon penghasil buah yang banyak ditemukan di nurseri yang diwakili oleh berbagai species seperti jambu biji, jambu air, jambu bol dan jambu mawar. Walaupun memiliki banyak spesies, namun (8 spesies), namun sebanyak 6 spesies berasl dari satu genus saja yaitu Syzygium. Banyaknya species Syzygium yang ditemukan diduga berhubungan dengan Sebagian besar Myrtaceae ditemukan di daerah tropis dan subtropis 
(Cronquist 1981) termasuk Indonesia. Syzygium aromaticum (cengkeh) merupakan penghasil minyak atsiri baik di daun dan bunga sehingga banyak digunakan sebagai aroma terapi dan juga sauna tradisional (Silalahi dan Nisyawati 2018).

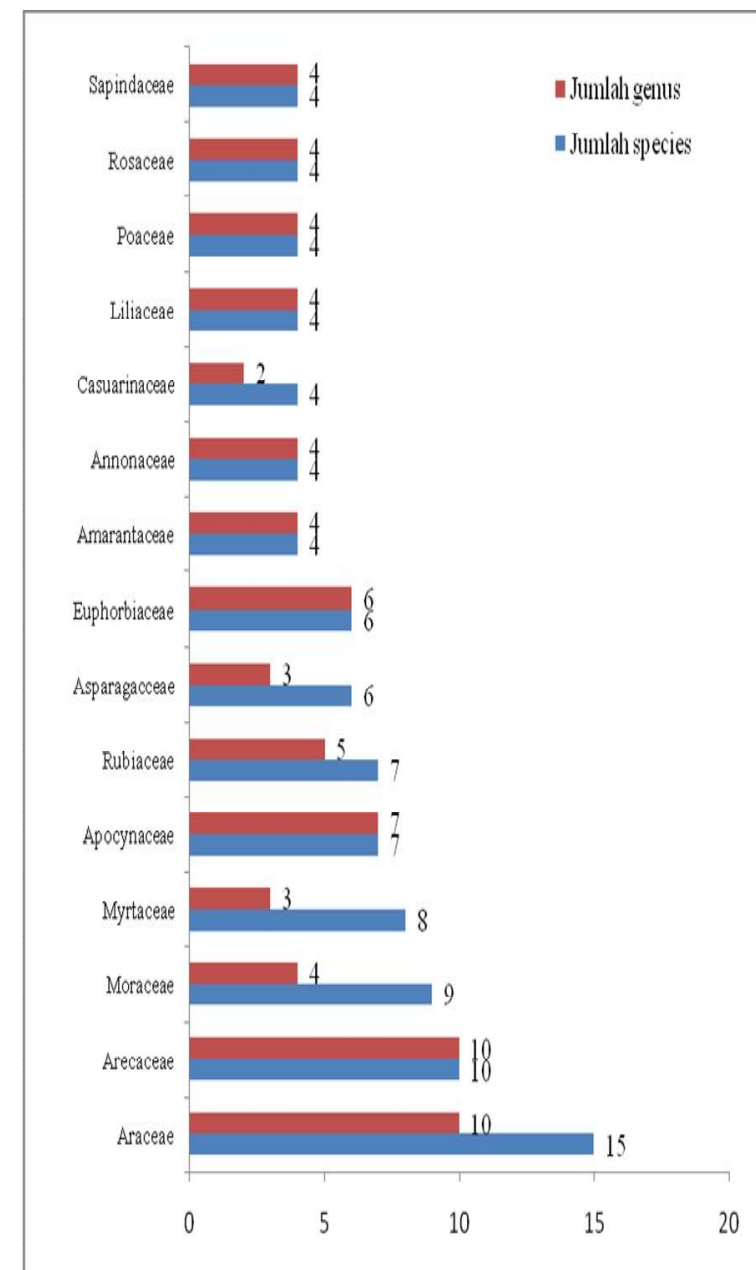

Gambar 1. Komposisi tumbuhan di nurseri Kranggan dengan famili yang memiliki jumlah spesies terbanyak.

Bila dilihat dari habitus, tumbuhan yang diperjualbelikan sebagian besar (86 spesies) merupakan herba, diikuti dengan pohon (69 species) dan paling sedikit adalah liana (Gambar 1). Herba merupakan tumbuhan berbatang basah dengan ukuran relatif kecil menjadikan tanaman ini menjadi salah satu pilihan yang tepat untuk dijadikan sebagai tanaman hias oleh berbagai kalangan masyarakat. Sebagian besar tanaman herba berasal dari famili
Araceae (Aglaonema spp, Anthurium spp.), Amaranthaceae (Celosia cristata, Amaranthus hybrida), Asparagaceae (Asparagus spp.) dan Liliaceae (Cordelium sp, Sansiviera sp). Beberapa jenis tanaman herba merupakan tanaman sukulen (berdaun tebal dan menyimpan air) sehingga tahan terhadap kekeringan seperti Aloe vera dan Sansiviera sp.

Sebagaian besar tanaman herba yang diperjual belikan memiliki struktur maupun warna dan warna daun yang menarik seperti Aglaonema spp., Sansiviera spp., Bromelia spp., dan Begonia spp. Walaupun sebagian herba berdaun sukulen, namun beberapa jenis herba merupakan tanaman yang menyenangi tempat lembab hingga berair seperti Phylodendron, Lotus spp. dan Ophioglossum sp.

Tumbuhan berhabitus perdu sebagian besar berasal dari famili Rosaceae (Rosa sp.), Rubiaceae (Ixora spp.), dan Verbenaceae (Lantana cama$r a$ ). Tumbuhan perdu memiliki bunga yang menarik dengan warna yang relatif cerah serta bervariasi dengan frekuensi berbunga relatif tinggi. Ixora $\mathrm{spp}$ dan Lantana camara yang diperjual belikan memiliki variasi warna pink, putih, kuning, dan merah dengan bunga majemuk sehingga memiliki jumlah bunga yang banyak (Gambar 2). Selain mengandalkan kelebihan warna bunga, struktur daun yang menarik dari segi warna maupun morfologi bentuk daun dimiliki oleh tanaman puring (Cordeum variegatum). 


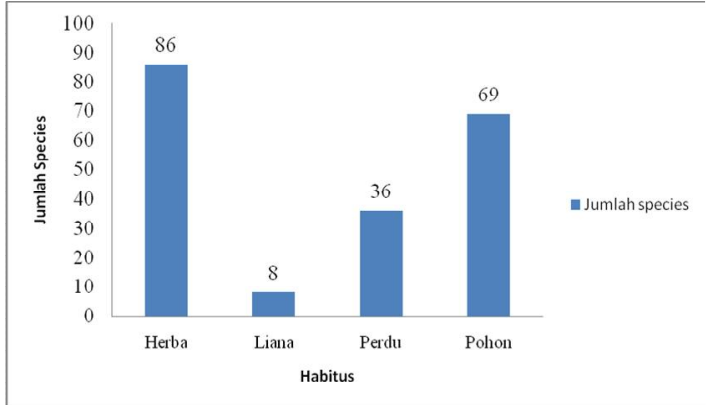

Gambar 2. komposisi tumbuhan yang diperjual-belikan di nurseri Kranggan dilihat dari habitusnya.

Terminalia cattappa, ketepang kencana (Terminalia mantaly), glodokan tiang (Polyalthia longifolia) merupakan beberapa jenis berhabitus pohon yang banyak digunakan sebagai peneduh, karena memiliki kanopi yang tinggi. Rambutan, klengkeng, jambu air, mangga, buah nona merupakan jenisjenis pohon yang menghasilkan buah. Ukuran pohon yang relatif besar dan harga yang relatif mahal menjadikan jumlah individu yang diperjual-belikan relatif sedikit. Tanaman buah yang dijual diperbanyak dengan cara vegetatif, hal tersebut dilakukan untuk mempercepat waktu berbuah sekaligus dapat menjamin kualitas buah sama dengan indukannya.

\section{KESIMPULAN}

1. Tumbuhan yang diperjual-belikan di nurseri Kranggan sangat bervariasi antara satu pedagang dengan pedangang lainnya yaitu antara 93-140 spesies tumbuhan.

2. Total keselurahan tumbuhan yang diperjual belikan di nurseri Kranggan 197 spesies yang termasuk dalam 158 g dan 76 famili.

3. Bila dilihat dari habitus, tumbuhan yang diperjual-belikan sebagian besar (86 spesies) merupakan herba, diikuti dengan pohon (69 species), perdu (36 species) dan liana (6 species).

\section{Ucapan Terima Kasih}

Penulis mengucapkan terima

kasih kepada Lembaga Penelitian dan
Pengabdian Masyarakat (LPPM)

Universitas Kristen Indonesia yang memberi dana dalam pelaksanaan penelitian ini. Terima kasih juga kepada pemilik, pengelola nursery Kranggan sebagai responden yang telah member informasi, dan juga kepada Lidia Juliven Sianturi dan Tri Putri Marito Siadari yang membantu pengumpulan data.

\section{DAFTAR PUSTAKA}

Boer, E. and Ella, A.B. (2001). Prosea (Plant resources of South-East Asia) 18: Plants producing exudates. Prosea, Bogor: $184 \mathrm{hlm}$.

Backer, C.A. and van Den Brink, B. (1965). Flora of Java (Spermatophyte Only): Vol. II. Angiospermae, families 111-160. N.V.P. Noordhoff, Groningen, $641 \mathrm{hlm}$.

Cronquist, A. (1981). An integrated system of classification of fower plants. Columbia University Press. New York.

Haque, MA., Miah, M.A.M. and Rashid, M.A. (2007). An economic study of plant nursery business in Gazipur and Jessore Districts of Bangladesh. Bangladesh J. Agril. Res. 32(3): 375-385.

Iskandar, B.D., Iskandar, J., Irawan, B. and Partasasmita, R. (2018). Traditional markets and diversity of edible plant trading: Case study in Ujung Berung, Bandung, West Java, Indonesia. Biodiversitas 19(3): 437-452

Martin, G.J. (1995). Ethnobotany a people and plants conservation manual. Chapman and Hall. London, UK. 67-136.

Nisyawati dan Silalahi M. (2015). Keanekeragaman Tumbuhan Obat di Pasar Berastagi. Laporan Hibah Penelitian Dikti. Departemen Biologi, FMIPA, Universitas Indonesia, Depok. 
Sihotang, H., Silalahi, M., and Murniarti, D. (2019). Manajamen Tanaman Di Nurseri Kranggan, Bekasi, Jawa Barat. Jurnal Pro-Life 6(1): 89-101. Silalahi, M. (2014). The ethnomedicine of the medicinal plants in subethnic Batak North Sumatra and the conservation perspective. [Diserta-tion]. Program Studi Biologi, Program Pasca Sarjana, FMIPA, Universitas Indonesia, Depok.

Kriswiyanti, E.I.K., Junitha, E.S., Kentjonowati, N., Darsini, and Setyawati, I. (2011). Inventarisasi bahan obat tradisional di Kecamatan Kintamani Kabupaten Bangli, Bali. Prosiding Seminar Nasional Konservasi Tumbuhan Tropika Kondisi Terkini dan Tantangan ke Depan Kebun Raya Cibodas 7 April 2011, Cibodas:108-112.

Silalahi, M., Nisyawati, Walujo, E.B., Supriatna, J., and Mangunwardoyo, W. (2015). The local knowledge of medicinal plants trader and diversity of medicinal plants in the Kabanjahe traditional market, North Sumatra, Indonesia. Journal of Ethnopharmacology 175: 432443.

Silalahi, M., and Nisyawati. (2018). An ethnobotanical study of traditional steam-bathing by the Batak people of North Sumatra, Indonesia. Pacific Conservation Biology https://doi.org/10.1071/PC18038; 1-17.

Supangkat, B. (2012). Market and Women Traders in Ujung Berung Market, Bandung. [Dissertation]. Depart-ment of Anthropology, Faculty of Social and Political Science, University of Indonesia. 